\title{
Pengaruh Kepemimpinan dan Pendidikan Terhadap Kinerja Prajurit Satuan Tugas Force Protection Company (FPC) XXVI-L2/Unifil dalam Mendukung Perdamaian di Lebanon Selatan
}

\author{
Felix Rizkha Firano \\ Program Studi Pascasarjana Wasantanas Universitas Brawijaya \\ Email: felixglamour@gmail.com
}

\begin{tabular}{l}
$\frac{1}{\text { Artikel info }}$ \\
\hline Artikel history: \\
Diterima 07 Mei 2021 \\
Diterima dalam bentuk \\
revisi 12 Mei 2021 \\
Diterima dalam bentuk \\
revisi 19 Mei 2021
\end{tabular}

Keywords:

leadership; education and

performance.

Kata Kunci:

kepemimpinan; pendidikan dan kinerja.

\begin{abstract}
Performance in an organization is an important asset that must be maintained because it is very necessary in an effort to realize the main tasks of the organization. One approach to improving performance can be done through the application of proper leadership and appropriate education. Leadership is needed by leaders in order to control the organization to achieve its goals. Meanwhile, education is very much needed in order to support the achievement of main tasks effectively and efficiently. The research was carried out in the unit because the XXVI-L2 Force Protection Company (FPC) Task Force is one of the Garuda Contingent Task Force assigned to maintain peace in the territory of the country of Lebanon. This research is a quantitative study with primary data obtained from questionnaires filled out by the respondents. The number of respondents was 100 people who were selected from various parts of the Force Protection Company (FPC) Task Force XXVI-L2. The purpose of this study was to analyze and look for the influence between leadership and education on performance. And the results of this research are expected to be useful in enriching theories related to human resource management and for the Task Force of the Force Protection Company (FPC) in South Lebanon in determining future policies so that they can optimize the performance of their soldiers.
\end{abstract}

\begin{abstract}
Abstrak: Kinerja dalam sebuah organisasi merupakan sebuah aset penting yang harus dijaga karena sangat diperlukan dalam upaya untuk mewujudkan tugas pokok organisasinya. Salah satu pendekatan dalam upaya meningkatkan kinerja tersebut dapat dilakukan melalui penerapan kepemimpinan yang tepat serta pendidikan yang sesuai. Kepemimpinan sangat diperlukan oleh pemimpin dalam rangka menahkodai organisasinya untuk mencapai tujuan. Sedangkan pendidikan sangat diperlukan dalam rangka mendukung pencapaian tugas pokok secara efektif dan efisien. Penelitian dilaksanakan di Satuan tersebut karena Satuan Tugas Force Protection Company (FPC) XXVI-L2 merupakan salah satu Satgas Kontingen Garuda yang ditugaskan untuk menjaga perdamaian di wilayah negara Lebanon. Penelitian ini merupakan penelitian kuantitatif dengan data primer diperoleh dari kuesioner yang diisi oleh para responden. Jumlah responden sebanyak 100 orang yang dipilih dari berbagai bagian di Satuan Tugas Force Protection Company (FPC) XXVI-L2. Tujuan penelitian ini adalah untuk mengalisis dan mencari pengaruh antara kepemimpinan dan pendidikan terhadap kinerja. Dan hasil dari penelitian ini, diharapkan dapat bermanfaat dalam pengayaan teori terkait manajemen sumber daya manusia dan bermanfaat bagi Satuan Tugas Force Protection Company (FPC) di Lebanon Selatan dalam menentukan kebijakan ke depan sehingga dapat mengoptimalkan kinerja prajuritnya.
\end{abstract}


Coresponden author: Felix Rizkha Firano

Email: felixglamour@gmail.com

artikel dengan akses terbuka dibawah lisensi

\section{Pendahuluan}

Lebanon merupakan suatu negara yang berada di Timur tengah, sepanjang Laut tengah kemudian memiliki batas dengan Suriah di utara dan timur, dan berbatasan dengan Israel di selatan yang berpenduduk kurang lebihi 4 juta jiwa (Diku, 2020). Diperkirakan bahwa 59\% penduduk Lebanon merupakan Muslim terdiri dari Sunni, Syi'ah, dan Druze. Kemudian 39\% adalah Kristen dan terdapat pula komunitas kecil Yahudi dan Kurdi. Selain itu negara Lebanon memiliki keadaan atau kondisi politik yang sangat khas atau bersifat sensitif, hal ini disebabkan dengan adanya banyaknya komunitas religius yang memiliki orientasi politik yang mendominasi pemerintahan Lebanon. Dengan adanya hal tersebut maka sistem politik Lebanon berdasarkan pada suatu prinsip atau keharusan adanya keadilan atau imbang pada setiap aspek kehidupan diantara banyaknya komunitas religius. Apabila keseimbangan ini terganggu maka kehidupan di Lebanon atau bahkan keutuhan negara Lebanon akan dapat terganggu.

Konflik sektarian tersebut dapat dihindari. Kemudian sistem ini berupaya untuk adil dalam mewakili aliran-aliran keagamaan dalam pemerintahan. Dengan hal itu, jabatan tinggi atau jabatan tertentu dalam pemerintahan disediakan untuk anggota kelompok dengan keagamaan tertentu. Seperti Presiden Lebanon yang mengharuskan dari Kristen Katolik Maronit, kemudian Perdana Menteri dari Muslim Sunni, Wakil Perdana Menteri dari Kristen Ortodoks, dan Ketua Parlemen dari Muslim Syi'ah (Zahar, 2005)

Permasalahan yang sering dibahas hingga saat ini adalah antara Hizbullah dengan Israel yang dimulai dari dilema keamanan di Lebanon dan Israel yang telah terjadi dan memiliki riwayat yang relatif panjang. Keamanan di wilayah Lebanon dan Israel kritis pada saat bulan Juli sampai Agustus 2006 sehingga memunculkan perseteruan antara kelompok Hizbullah yang terdapat di Lebanon dengan Israel. Perseteruan antara Israel dengan para gerilyawan Hizbullah dimulai dari penawanan dua prajurit Israel, Ehud Goldwasser serta Eldad Regev, oleh milisi Hizbullah (Prakoso, 2007). Kemudian Israel berusaha untuk membebaskan dua milisinya dengan cara melakukan suatu agresi militer menyerang Lebanon, menghancurkan prasarana dan sarana umum dan membunuhi penduduk sipil. sementara pihak Hizbullah pun melakukan perlawanan dengan menghujani daerah Utara Israel dengan roket. Perseteruan yang terjadi di Lebanon tadi adalah akibat asal Perang Saudara Lebanon yg terjadi di tahun 1975 sampai dengan 1990 yang dipicu oleh efek konflik regional sekitarnya yg bermula berasal konfrontasi pengungsi Palestina PLO (Palestine Liberation Organization) menggunakan partai komunis serta sosialis pada Lebanon.

Konfrontasi ini semakin parah dengan banyaknya pihak-pihak yang terlibat seperti Phalangist, Druze Forces, Maronite serta Muslim Suni. Selain itu pihak negara ada yang melibatkan diri dalam pertarungan tersebut, diantaranya adalah Suriah dan Israel. Pada sekitar bulan Juni 1976, Suriah mengirimkan 40.000 milisi menuju ke Lebanon dalam rangka 
mencegah milisi Maronites dihancurkan oleh Palestinian Ezzat Forces. Suriah dan Maronites mendorong Palestina keluar asal Beirut hingga masuk ke wilayah selatan Lebanon. Dalam beberapa tahun berikutnya, perubahan suasana politik menyebabkan Suriah bersekutu dengan Palestina serta sebagian Maronit bersekutu dengan Israel, sedangkan pasukan Suriah tetap di Lebanon. Beberapa agresi lintas batas oleh grup Palestina (PLO) pada wilayah selatan Lebanon terhadap warga sipil pada daerah Israel membentuk IDF (Israeli Defense Force) menyerbu masuk Lebanon pada 14 Maret 1978 serta memberi nama operasi Litani River.

Selanjutnya pada tanggal 19 Maret 1978, Dewan Keamanan Perserikatan BangsaBangsa atau DK PBB mengeluarkan suatu Resolusi 425 dan 426 yang berisi perintah penarikan milisi Israel dan penyingkiran milisi Palestina, dan sekaligus membentuk pasukan internasional penjaga perdamaian di Selatan Lebanon, UNIFIL (United Nations Interim Force in Lebanon) (Cobban, 1984). Akhirnya pada tahun 1978 Israel merampungkan penarikan pasukannya dan mengalihkan kendali di Selatan Lebanon kepada South Lebanon Army (SLA). Sementara itu milisi Palestina tetap berada di wilayah tersebut yang kemudian melanggar perjanjian gencatan senjata PBB. Pada tanggal 6 Juni 1982, milisi Israel menginvasi Lebanon dengan tujuan menghalau PLO dengan alasan PLO telah menembak Dubes Israel di London yang bernama Shlomo Argov, walaupun PLO telah membantah keterlibatannya dalam usaha penembakan Dubes tersebut.

Konflik bersenjata kembali muncul di tahun 2006. Berawal dari milisi Hizbullah yang menculik dua milisi Israel. Penculikan tersebut meningkatkan ketegangan di kawasan perbatasan. Milisi Israel kemudian merespon dengan menyerang Hizbullah yang berada di wilayah Selatan Lebanon dan mengakibatkan pada peperangan yang terjadi lebih dari satu bulan. Berawal dari serangan tersebut, tidakan saling counter tidak dapat dihindari oleh Israel Defence Forces (IDF) dengan Hizbullah. Serangan tersebut melewati Garis Biru (Blue Line) yang telah ditetapkan oleh PBB. Hizbullah menyerang basis pasukan IDF dan kota-kota Israel diselatan Garis Biru. Israel kemudian membalas penyerangan dari darat, udara dan laut. Konflik Israel-Hizbullah yang terjadi di Lebanon akhirnya mendapatkan perhatian PBB. Upaya merestorasi perdamaian mendapatkan berbagai hambatan, khususnya penolakan dari sekutu dekat Israel yaitu Amerika Serikat (AS). Setelah melakukan negosiasi dengan berbagai pihak, Dewan Keamanan (DK) PBB berhasil mengeluarkan resolusi 1701 pada tahun 11 Agustus 2006 yang menyatakan perlunya penambahan personil UNIFIL serta penegasan dan penambahan kewenangan UNIFIL dalam menangani instabilitas keamanan di Lebanon Selatan, sebagai respon atas serangan Israel ke Lebanon pertengahan tahun 2006.

Melaksanakan tugas perdamaian dunia sesuai dengan kebijakan politik luar negeri republik Indonesia merupakan salah satu tugas pokok TNI dalam UU No 34 tahun 2004 tentang TNI. Hal ini sesuai dengan nilai yang terkandung dalam pembukaan UUD 1945, dimana salah satu tujuan nasional Indonesia adalah ikut serta dalam melaksanakan ketertiban dunia yang berdasarkan kemerdekaan, perdamaian abadi, dan keadilan sosial. Berdasarkan hal tersebut sampai dengan saat ini Negara Indonesia selalu mengirimkan Kontingen Garuda untuk bergabung dengan misi perdamaian dunia dibawah bendera PBB. Kontingen Garuda dikirim ke berbagai negara di dunia untuk melaksanakan misi perdamaian PBB.

Pengiriman pasukan dalam misi perdamaian PBB memiliki arti penting terkait dengan pendekatan terhadap masyarakat di negara dimana misi tersebut dilaksanakan. Keadaan tersebut dapat dikaitkan dengan tugas dan tanggung jawab yang tidak dapat dilepaskan 
dengan interaksi diantara pasukan TNI dengan masyarakat dimana pasukan tersebut ditempatkan. Hal tersebut dapat membuktikan bahwa negara Indonesia sangat aktif dalam misi perdamaian khususnya yang berada dibawah PBB.

Pengiriman TNI ke luar negeri pada misi perdamaian merupakan representasi dari Negara Kesatuan Republik Indonesia (NKRI) sebagai suatu negara. Pasukan TNI yang menjadi bagian dari misi perdamaian PBB akan membuka peluang besar untuk membantu hubungan sosial antara TNI sebagai representasi atau gambaran dari Indonesia dengan masyarakat sekaligus dengan kontingen pasukan dari negara lain dalam misi PBB tersebut. Salah satu negara dimana pasukan TNI paling banyak ditempatkan adalah di Lebanon Selatan dalam misi UNIFIL, dimana dalam upaya pemeliharaan perdamaian pasukan TNI memiliki kesempatan untuk berinteraksi langsung dengan masyarakat lokal sekaligus dengan kontingen pasukan penjaga perdamaian dari negara lain.

Bagi Indonesia, keberadaan TNI sebagai bagian dari UNIFIL diposisikan sebagai implementasi dari kebijakan luar negeri bebas aktif. Peran Indonesia dalam keterlibatan TNI yang menjadi bagian dari UNFIL merupakan salah satu bentuk dari implementasi keaktifan Indonesia dalam ikut serta pada setiap upaya menciptakan perdamaian dunia. Walaupun dengan tujuan dari kebijakan luar negeri yang baik, namun resistensi penerapan kebijakan luar negeri bebas aktif tersebut tidak terlepas dari resistensi baik dari negara lain maupun khususnya masyarakat di negara tujuan misi. Kontingen Garuda (Konga) UNIFIL yang melaksanakan tugas perdamaian PBB di Lebanon selatan. UNIFIL yang berdiri sejak 1978 untuk menengahi konflik antara Lebanon dengan Israel. Saat ini UNIFIL memiliki 45 TCC (Troops Countributing Country) diantaranya adalah Indonesia. Kontingen Garuda pada tahun 2020 mengirimkan 7 Satuan penugasan, salah satunya adalah Satgas FPC XXVI-L2 /UNIFIL.

Satgas FPC XXVI-L2 secara umun bertugas dalam menjamin pengamanan sektor Naqoura HQ (Green Hill) yang merupakan bagian tanggung jawab Indo Force Protection Company ditempatkan petugas jaga di main gate, observation post (OP) dan Patroli (Tahupelasury, 2020). Tugas pokok yang pertama di main gate yaitu melaksanakan pengecekan setiap orang, barang dan kendaraan yang keluar masuk melalui pintu utama tersebut, sehingga mampu mencegah segala hambatan, tantangan, gangguan dan segala bentuk ancaman yang dapat datang dari dalam camp maupun dari luar camp.

Kemudian dalam melaksanakan pengamanan melalui OP diselenggarakan dengan pengamatan secara terbuka melalui pos-pos yang berada di sekeliling kamp terhadap situasi dan kegiatan personel militer, penduduk sipil ataupun kelompok bersenjata. Bentuk dari Observation Post merupakan pos pengamatan yang berbentuk permanen (tetap) dan statis serta tersebar dalam beberapa titik secara perimeter di area Green Hill. Pelaksanaan Observation Post memiliki arti yang penting dalam menghadapi kemungkinan-kemungkinan bahaya dan ancaman yang mungkin terjadi. Dalam pelaksanaannya, petugas jaga berkedudukan di Observation Post berkekuatan minimal 2 orang dengan dilengkapi peralatan untuk mendukung pengamatan dan pengawasan serta berkoordinasi dengan sesama dan unsur dinas jaga lainnya agar dapat menjamin keamanan di Naquora Camp Green Hill terhadap kemungkinan ancaman baik dari dalam maupun dari luar. 
Tugas dan tanggung jawab yang secara rutin dilaksanakan dalam rangka mengamankan Naqoura Extension (Green Hill) yang terakhir yaitu melaksanakan kegiatan patroli. Dalam pelaksanaanya patrol dilaksanakan menggunakan metode dengan kendaraan maupun dengan berjalan kaki. Patroli dilaksanakan dengan jumlah personel patroli jalan kaki berkekuatan 1 regu yang terdiri dari 7 orang bersenjata. Susunan organisasi dalam pelaksanaan patroli Strada dalam Green Hill apabila status siaga green atau yellow maka menggunakan 1 kendaraan Strada sedangkan dalam kondisi status siaga red tidak menggunakan kendaraan Strada melainkan kendaraan Armoured Personel Carrier (APC).

Sumber Daya Manusia (SDM) merupakan salah satu faktor penting yang harus dijaga atau dipelihara pada sebuah organisasi atau Institusi. Tidak hanya pada organisasi sipil namun hal ini juga berlaku pada institusi militer khususnya Tentara Nasional Indonesia (TNI). Dalam struktur organisasi TNI di dalamnya terdapat banyak anggota atau prajurit. TNI dituntut untuk mampu mengoptimalkan kinerja prajuritnya. Salah satu upaya dalam rangka meningkatkan kinerja prajurit dapat dilakukan dengan penerapan kepemimpinan yang tepat serta pendidikan yang sesuai. Kepemimpinan diperlukan dalam rangka memimpin organisasinya untuk mencapai tujuan. Sedangkan pendidikan diperlukan untuk mendukung tugas pokok secara efektif dan efisien. Oleh karena itu penelitian ini akan membahas mengenai kinerja prajurit yang dihubungkan dengan kepemimpinan dan pendidikannya (Yuniarti \& Suprianto, 2020).

Dari berbagai permasalahan yang terjadi tersebut memerlukan peran serta prajurit Tentara Nasional Indonesia dalam proses pencegahannya maupun tindak lanjutnya. Dengan diperlukannya peran serta prajurit Tentara Nasional Indonesia tersebut maka diperlukan adanya kinerja yang baik dari prajurit Tentara Nasional Indonesia sehingga setiap tugas yang diberikan dapat terlaksana dengan baik.

Ilmu pengetahuan tentang berbagai hal yang terkait dengan kepemimpinan di dunia ini sepertinya merupakan pokok bahasan yang senantiasa menarik untuk dipelajari sekaligus diperdebatkan. Sebagai contoh, ada yang menganggap bahwa kepemimpinan merupakan sebuah "seni" dan di sisi lain dianggap sebagai sebuah "ilmu". Kepemimpinan dianggap sebagai sebuah "seni" karena merupakan sebuah bakat yang melekat sejak lahir dan setiap orang mempunyai ciri khas yang berbeda-beda. Menurut (Perry \& Potter, 2016) pemimpin adalah individu yang mampu mempengaruhi perilaku orang lain tanpa harus mengandalkan kekerasan. Kepemimpinan merupakan salah satu teknik atau cara untuk mempengaruhi orang lain untuk dapat mencapai tujuan tertentu. Dalam prakteknya kepemimpinan akan berbeda antara orang satu dengan lainya.

Dalam bidang militer terutama Tentara Nasional Indonesia (TNI), terdapat perbedaan pemahaman tentang kepemimpinan dibandingkan dengan pendapat ahli yang lainnya. Konsep kepemimpinan yang diterapkan yaitu kepemimpinan lapangan. Kepemimpinan ini memiliki ciri khas yaitu suatu pola kepemimpinan yang dilakukan tidak hanya duduk di kantor namun juga harus mampu membaur dan bekerja sama di lapangan secara langsung. Dalam pelaksanaannya kepemimpinan lapangan akan berbeda dengan kepemimpinan lainnya karena pada kepemimpinan lapangan seorang pemimpin akan bertemu dengan anggota secara langsung. Pertemuan langsung dengan anggota akan dapat memberikan efek secara langsung kepada pemimpin seperti keloyalan pada pimpinannya tersebut. Dengan perbedaan pemahaman tentang kepemimpinan oleh para ahli serta perbedaan pemahaman dalam 
perspektif militer, penulis menjadikan kepemimpinan sebagai salah satu variabel bebas dalam penelitian ini.

Faktor pendidikan juga tidak kalah penting dalam mempengaruhi kinerja sebuah organisasi. Salah satu contoh pendidikan menjadi faktor penting pada saat melamar pekerjaan, karena akan tercantum syarat minimal pendidikan di setiap lowongan pekerjaan. Hal tersebut didasarkan karena setiap pekerjaan yang berbeda tujuan pokoknya. Kinerja suatu organisasi sangat ditentukan oleh tingkat pendidikan di setiap anggota atau pegawainya. Organisasi atau badan instansi apalagi yang bersangkutan dengan pembangunan bangsa dan negara sangat penting memiliki pegawai atau anggota yang memiliki sumber daya manusia (SDM) yang baik.

Dalam suatu kondisi ketika tingkat pendidikan tidak sesuai dengan perencanaan kerja yang dilaksanakan maka akibatnya kinerja yang dilakukan pegawai tidak seperti yang direncanakan sebelumnya. Sehingga organisasi atau instansi pemerintahan harus melihat sumber daya manusia dan segi tingkat pendidikannya. Sebagaimana tujuan dan harapan dari tingkat pendidikan adalah untuk meningkatkan kinerja pegawai yang dihasilkan melalui sumber daya manusia (SDM) yang ada pada suatu instansi atau organisasi baik kualitas kerja yang dihasilkannya.

Sedangkan menurut (Priatna, 2004), pendidikan merupakan aktivitas yang disengaja untuk mencapai tujuan tertentu dan melibatkan berbagai faktor yang saling berkaitan satu dan lainnya sehingga membentuk satu sistem yang saling mempengaruhi. Dengan pentingnya pendidikan ini, organisasi militer khususnya TNI telah merumuskan beberapa kebijakan terkait pendidikan yang diantaranya yaitu adanya persyaratan pendidikan minimal, adanya persyaratan nilai minimal serta adanya materi akademis. Selain itu TNI juga melaksanakan pembinaan dengan menyelenggarakan kegiatan pendidikan bagi anggotanya dalam rangka meningkatkan kualitas. Dengan pentingnya pendidikan sesuai uraian di atas, penulis pendidikan sebagai salah satu variabel bebas (independen) dalam penelitian ini.

Beberapa ahli merumuskan pengertian tentang kinerja, diantaranya menurut (Amstrong \& Baron, 2004) kinerja merupakan hasil pekerjaan yang mempunyai hubungan kuat dengan tujuan strategis organisasi, kepuasan konsumen dan memberikan kontribusi ekonomi. Pandangan lain dikemukakan oleh (Bastian, 2001) kinerja adalah gambaran mengenai tingkat pencapaian pelaksanaan suatu kegiatan/program/kebijaksanaan dalam mewujudkan sasaran, tujuan, misi dan visi organisasi yang tertuang dalam perumusan skema strategis (Strategic Planning) suatu organisasi. Pada organisasi militer, penilaian kinerja terhadap setiap prajurit juga dilakukan. Penilaian terhadap seorang prajurit dilaksanakan oleh Atasan langsung dari prajurit tersebut. Hasil penilaiannya dituangkan dalam bentuk surat dengan nama "Daftar Penilaian”. Isi dari surat tersebut berisi penilaian tentang aspek kepribadian dan aspek kecakapan. Surat tersebut selalu dijadikan salah satu persyaratan dalam peningkatan karir setiap prajurit. Jika hasil penilaian kinerjanya tidak memenuhi batas minimal yang ditentukan, maka prajurit yang bersangkutan akan terhambat karirnya sebagai contoh tidak bisa naik pangkat ataupun tidak bisa melaksanakan pendidikan. Dengan pentingnya kinerja sesuai uraian di atas, penulis menjadikan kinerja sebagai variabel tetap (dependen) dalam penelitian ini.

Terkait hal tersebut, tentunya perlu diketahui tentang kriteria kinerja yang baik bagi 
seorang prajurit yaitu dapat dilihat dari tingkat keprofesionalan prajurit, tingkat kedisiplinan prajurit, tingkat penyelesaian tugas prajurit baik secara kuantitas maupun kualitas serta tingkat kerja sama prajurit. Maksud dari Tentara Profesional adalah tentara yang mahir menggunakan alat dan peralatan militer, mahir bergerak dan mahir menggunakan alat tempur atau Alutsista serta mampu menjalankan tugas secara terukur dan memenuhi pokok nilai-nilai akuntabilitas. Sedangkan disiplin adalah suatu perilaku yang muncul dan dapat menyesuaikan diri dengan aturan yang ada atau yang telah ditetapkan. Pada penyelesaian tugas secara kuantitas berarti terkait selesai atau tidaknya tugas yang diberikan dengan pembatasan waktu yang telah ditetapkan, sedangkan secara kualitas dengan mempertimbangkan kesesuaian dengan antara hasil dengan standar yang telah ditetapkan. Selain itu juga perlu diperhatikan mengenai tingkat kerja samanya karena di dalam organisasi militer terdiri dari banyak personel dengan berbagai tugasnya masing-masing yang saling terkait.

Dengan mempertimbangkan keseluruhan uraian latar belakang di atas. maka penulis mengadakan penelitian di tempat penugasan, yaitu di Satuan Tugas (Satgas) Force Protection Company (FPC) di Lebanon Selatan dengan judul: "Pengaruh Kepemimpinan Dan Pendidikan Terhadap Kinerja Prajurit Satuan Tugas Force Protection Company (FPC) XXVI-L2 / UNIFIL dalam Mendukung Perdamaian di Lebanon Selatan”.

\section{Metode Penelitian}

Pada penelitian ini yang digunakan adalah penelitian survei melalui pendekatan kuantitatif karena tujuan penelitian yang akan dilakukan adalah untuk mencari hubungan antara beberapa variabel serta teknik pengumpulan datanya menggunakan angket yang disebar terhadap beberapa sampel yang diharapkan mewakili populasi secara keseluruhan. Hal tersebut dikategorikan sebagai penelitian survei dikarenakan apa yang akan dikerjakan pada penelitian ini sesuai dengan pendapat para ahli diantaranya Fred N. Kerlinger dan David Kline. Menurut Kerlinger yang dikutip oleh (Sugiyono, 2018), "Survey Research studies large and small population (or universes) by selecting and studying samples chosen from the population to discover the relative incident, distribution and interrelations of sociological and psychological variables".

\section{Hasil dan Pembahasan}

\section{Uji Validitas.}

Uji validitas dilakukan terhadap instrumen kuesioner untuk mengetahui seberapa jauh korelasi item-item pertanyaan/pernyataan yang ada pada kuesioner terhadap jumlah keseluruhan variabel penelitian. Rumus yang digunakan pada penghitungan validitas di penelitian ini adalah rumus Pearson Product Moment sebagai berikut:

$$
r X Y=\frac{N \Sigma X Y-(\Sigma X)(\Sigma Y)}{\left.\sqrt{\left(N \Sigma X^{2}-(\Sigma X)^{2}\right)\left(N \Sigma Y^{2}-(\Sigma Y\right.}\right)^{2}}
$$

\section{Keterangan:}

$\mathrm{rXY}=$ Koefisien korelasi.

$\mathrm{N} \quad=$ Jumlah sampel.

$\Sigma \mathrm{X}=$ Jumlah skor keseluruhan untuk item pertanyaan variabel $\mathrm{X}$. 
$\Sigma \mathrm{Y}=$ Jumlah skor keseluruhan untuk item pertanyaan variabel $\mathrm{Y}$.

Berdasarkan ketentuan rumus tersebut, kriteria yang ditentukan dalam menentukan valid tidaknya sebuah pernyataan untuk digunakan sebagai instrumen dalam penelitian ini adalah sebagai berikut:

1. Jika $r X Y \geq 0,3$, maka item - item pernyatan tersebut dinyatakan valid.

2. Jika $\mathrm{r} X Y<0,3$, maka item - item pernyatan tersebut dinyatakan tidak valid.

Setelah diperoleh data dari hasil kuesioner kemudian dilaksanakan pengolahan data menggunakan rumus Pearson Product Moment, diperoleh hasil sebagai berikut:

Tabel 1.

\begin{tabular}{|c|c|c|c|}
\hline No & r Hitung & r Kritis & Keputusan \\
\hline $\mathbf{r 1 y}$ & 0,36 & 0,3 & Valid \\
\hline $\mathbf{r} 2 y$ & 0,32 & 0,3 & Valid \\
\hline r3y & 0,41 & 0,3 & Valid \\
\hline r4y & 0,41 & 0,3 & Valid \\
\hline r5y & 0,48 & 0,3 & Valid \\
\hline r6y & 0,51 & 0,3 & Valid \\
\hline r7y & 0,48 & 0,3 & Valid \\
\hline r8y & 0,51 & 0,3 & Valid \\
\hline r9y & 0,40 & 0,3 & Valid \\
\hline r10y & 0,71 & 0,3 & Valid \\
\hline r11y & 0,53 & 0,3 & Valid \\
\hline r12y & 0,43 & 0,3 & Valid \\
\hline r13y & 0,33 & 0,3 & Valid \\
\hline r14y & 0,59 & 0,3 & Valid \\
\hline $\mathbf{r} 15 y$ & 0,66 & 0,3 & Valid \\
\hline r16y & 0,62 & 0,3 & Valid \\
\hline r17y & 0,42 & 0,3 & Valid \\
\hline r18y & 0,50 & 0,3 & Valid \\
\hline r19y & 0,76 & 0,3 & Valid \\
\hline r20y & 0,48 & 0,3 & Valid \\
\hline r21y & 0,38 & 0,3 & Valid \\
\hline r22y & 0,41 & 0,3 & Valid \\
\hline $\mathbf{r} 23 y$ & 0,43 & 0,3 & Valid \\
\hline r24y & 0,60 & 0,3 & Valid \\
\hline r25y & 0,35 & 0,3 & Valid \\
\hline r26y & 0,61 & 0,3 & Valid \\
\hline r27y & 0,33 & 0,3 & Valid \\
\hline r28y & 0,79 & 0,3 & Valid \\
\hline r29y & 0,57 & 0,3 & Valid \\
\hline
\end{tabular}




\begin{tabular}{llll}
\hline $\mathbf{r 3 0 y}$ & 0,33 & 0,3 & Valid \\
$\mathbf{r 3 1 y}$ & 0,56 & 0,3 & Valid \\
$\mathbf{r 3 2 y}$ & 0,57 & 0,3 & Valid \\
$\mathbf{r 3 3 y}$ & 0,52 & 0,3 & Valid \\
$\mathbf{r 3 4 y}$ & 0,45 & 0,3 & Valid \\
$\mathbf{r 3 5 y}$ & 0,84 & 0,3 & Valid \\
$\mathbf{r 3 6 y}$ & 0,43 & 0,3 & Valid \\
$\mathbf{r 3 7 y}$ & 0,46 & 0,3 & Valid \\
$\mathbf{r 3 8 y}$ & 0,60 & 0,3 & Valid \\
$\mathbf{r 3 9 y}$ & 0,52 & 0,3 & Valid \\
$\mathbf{r 4 0 y}$ & 0,44 & 0,3 & Valid \\
$\mathbf{r 4 1 y}$ & 0,43 & 0,3 & Valid \\
$\mathbf{r 4 2 y}$ & 0,62 & 0,3 & Valid \\
$\mathbf{r 4 3 y}$ & 0,60 & 0,3 & Valid \\
$\mathbf{r 4 4 y}$ & 0,41 & 0,3 & Valid \\
$\mathbf{r 4 5 y}$ & 0,64 & 0,3 & Valid \\
$\mathbf{r 4 6 y}$ & 0,45 & 0,3 & Valid \\
\hline $\mathbf{r 4 7 y}$ & $\mathbf{0 , 3 9}$ & $\mathbf{0 , 3}$ & Valid \\
\hline
\end{tabular}

Berdasarkan hasil di atas, diperoleh data bahwa keseluruhan $r$ hitung untuk variable kepemimpinan, pendidikan dan kinerja lebih besar dari $r$ kritis. Hal tersebut berarti bahwa tiap item pertanyaan pada kuesioner yang digunakan pada penelitian ini termasuk valid.

\section{Uji Reliabilitas.}

Uji reliabilitas dilakukan terhadap instrumen kuesioner untuk mengetahui keandalan alat ukur yang digunakan pada penelitian dengan menggunakan rumus Alpha Cronbach. Berdasarkan ketentuan rumus tersebut, kriteria yang ditentukan dalam menentukan reliabel atau tidaknya sebuah pernyataan untuk digunakan sebagai instrumen dalam penelitian ini adalah jika memberikan nilai Alpha Cronbach r > 0,60. Rumus Alpha Cronbach yang digunakan pada penghitungan reliabilitas pada penelitian ini sebagai berikut:

$$
r=\frac{k}{k-1}\left(\frac{\left.1-\Sigma \alpha b^{2}\right)}{\alpha t^{2}}\right)
$$

\section{Keterangan:}

$\mathrm{r}=$ Reliabilitas instrumen.

$\mathrm{k} \quad=$ Banyaknya butir pertanyaan.

$\alpha b=$ Varian skor keseluruhan.

$\alpha \mathrm{t}=$ Varian total.

Setelah diperoleh data dari hasil kuesioner kemudian dilaksanakan pengolahan data menggunakan rumus Alpha Cronbach di atas, sehingga diperoleh hasil sebagai berikut:

\begin{tabular}{llll}
\hline No & r Hitung & r Kritis & Keputusan \\
\hline
\end{tabular}




\begin{tabular}{llll}
\hline $\mathbf{r} \mathbf{X}_{\mathbf{1}}$ & 1,06 & 0,6 & Reliabel \\
$\mathbf{r} \mathbf{X}_{\mathbf{2}}$ & 1,11 & 0,6 & Reliabel \\
\hline $\mathbf{r ~ Y}$ & $\mathbf{1 , 0 5}$ & $\mathbf{0 , 6}$ & Reliabel \\
\hline
\end{tabular}

Berdasarkan data di atas, diperoleh hasil bahwa keseluruhan $r$ hitung untuk variabel kepemimpinan, pendidikan dan kinerja lebih besar dari 0,6. Hal tersebut berarti bahwa tiap item pertanyaan pada kuesioner yang digunakan pada penelitian ini termasuk reliabel.

\section{Uji Hipotesis.}

\section{Hubungan antara Kepemimpinan dengan Kinerja Prajurit.}

Penghitungan korelasi variabel kepemimpinan dengan kinerja menggunakan rumus korelasi Product Moment sebagai berikut:

$$
\begin{aligned}
\mathrm{rX}_{1} \mathrm{Y} & =\frac{\Sigma \mathrm{X} \mathrm{Y}}{\sqrt{\left(\Sigma \mathrm{X}^{2}\right)\left(\Sigma \mathrm{Y}^{2}\right)}} \\
& =\frac{1.889,08}{\sqrt{5.596,36 \times 4.639,24}} \\
& =0,38
\end{aligned}
$$

Jadi terdapat korelasi yang positif sebesar 0,38 antara variabel kepemimpinan dengan variabel kinerja. Selanjutnya perlu dicari tahu tentang tingkat signifikasinya, apakah harga tersebut signifikan atau tidak. Bila menggunakan penghitungan dengan $\mathrm{r}$ tabel untuk $\mathrm{n}=100$ dan kesalahan $5 \%$, maka diperoleh nilai $\mathrm{r}$ tabel $=0,195$ sedangkan untuk nilai $\mathrm{r}$ hitung = 0,38. Ketentuan bila nilai $r$ hitung lebih kecil dari nilai $r$ tabel, maka Ho diterima dan $\mathrm{Hi}$ ditolak. Tetapi sebaliknya bila nilai $r$ hitung lebih besar dari $\mathrm{r}$ tabel $(\mathrm{r} h>\mathrm{r}$ t) maka Hi diterima. Dari hasil terlihat bahwa nilai $r$ hitung lebih besar dari nilai $r$ tabel maka Ha diterima, dengan demikian korelasi 0,38 itu positif dan signifikan.

\section{Hubungan antara Pendidikan dengan Kinerja Prajurit.}

Penghitungan korelasi variabel kepemimpinan dengan kinerja menggunakan rumus korelasi Product Moment sebagai berikut:

$$
\begin{aligned}
r_{2} Y & =\frac{\sum X Y}{\sqrt{\left(\Sigma X^{2}\right)\left(\Sigma Y^{2}\right)}} \\
& =\frac{629,11}{\sqrt{1.303,31 \times 3.984,91}} \\
& =0,0,28
\end{aligned}
$$


Jadi terdapat korelasi yang positif sebesar 0,28 antara variabel kepemimpinan dengan variabel kinerja. Selanjutnya perlu dicari tahu tentang tingkat signifikasinya, apakah harga tersebut signifikan atau tidak. Bila menggunakan penghitungan dengan $\mathrm{r}$ tabel untuk $\mathrm{n}=100$ dan kesalahan $5 \%$, maka diperoleh nilai $\mathrm{r}$ tabel $=0,195$ sedangkan untuk nilai $\mathrm{r}$ hitung $=$ 0,28. Ketentuan bila nilai $r$ hitung lebih kecil dari nilai $r$ tabel, maka Ho diterima dan Hi ditolak. Tetapi sebaliknya bila nilai $r$ hitung lebih besar dari $r$ tabel $(r \mathrm{~h}>\mathrm{r}$ t) maka Hi diterima. Dari hasil terlihat bahwa nilai $\mathrm{r}$ hitung lebih besar dari nilai $\mathrm{r}$ tabel maka $\mathrm{Ha}$ diterima, dengan demikian korelasi 0,28 itu positif dan signifikan.

\section{Hubungan antara Kepemimpinan dan Pendidikan dengan Kinerja Prajurit.}

Penghitungan korelasi antara variabel kepemimpinan dan pendidikan secara bersamasama terhadap kinerja prajurit pada hipotesis menggunakan rumus Korelasi ganda. Tetapi sebelum menghitung korelasi antara variabel kepemimpinan dan pendidikan secara bersamasama terhadap variabel kinerja, terlebih dahulu harus dihitung korelasi antar variabel independennya yaitu kepemimpinan dan pendidikan. Penghitungan korelasinya menggunakan rumus korelasi Product Moment sebagai berikut:

$$
\begin{aligned}
r X_{1} X_{2} & =\frac{\sum X Y}{\sqrt{\left(\Sigma X^{2}\right)\left(\Sigma Y^{2}\right)}} \\
& =\frac{951,88}{\sqrt{4.244,24 \times 1.303,31}} \\
& =0,40
\end{aligned}
$$

Setelah diperoleh hasil dari penghitungan korelasi antara 2 (dua) variabel independen di atas, selanjutnya hasil-hasil penghitungan korelasi dimasukkan ke rumus korelasi ganda. Adapun rekapan korelasi antar variabel sebagai berikut:

Tabel 2.

\begin{tabular}{llll}
\hline Var. & r Hitung & r Tabel & Keputusan \\
\hline $\mathbf{r} \mathbf{X}_{\mathbf{1}} \mathbf{Y}$ & 0,38 & 0,195 & Signifikan \\
$\mathbf{r} \mathbf{X}_{\mathbf{2}} \mathbf{Y}$ & 0,28 & 0,195 & Signifikan \\
\hline $\mathbf{r} \mathbf{X}_{\mathbf{1}} \mathbf{X}_{\mathbf{2}}$ & $\mathbf{0 , 4 0}$ & $\mathbf{0 , 1 9 5}$ & Signifikan \\
\hline
\end{tabular}

Penghitungan korelasi variabel kepemimpinan dan pendidikan secara bersama-sama terhadap kinerja menggunakan rumus korelasi ganda sebagai berikut:

$$
\begin{aligned}
& R X_{1} X_{2} Y \sqrt{\frac{r^{2} x_{1} y+r^{2} x_{2} y-2 r x_{1} y r x_{2} y_{r x} x_{2}}{=}} \\
& 1-\mathrm{r}^{2} \mathrm{x}_{1} \mathrm{x}_{2} \\
& =\sqrt{\frac{3,38^{2}+0,28^{2}-2(0,38)(0,28)(0,40)}{1-0,40^{2}}}
\end{aligned}
$$




$$
=0,405
$$

Jadi terdapat korelasi positif antara kepemimpinan dan pendidikan secara bersamasama dengan kinerja sebesar 0,405. Hubungan ini secara kualitatif dapat dinyatakan sedang dan besarnya lebih dari korelasi individual antara X1 dengan $\mathrm{Y}$ maupun X2 dengan $\mathrm{Y}$. Korelasi sebesar 0,405 itu baru berlaku untuk sampel yang diteliti. Apakah koefisien korelasi itu dapat digeneralisasikan atau tidak, maka harus diuji signifikasinya. Untuk menguji signifikasinya digunakan rumus F. Penghitungan signifikasi koefisien korelasi variabel kepemimpinan dan pendidikan secara bersama-sama terhadap kinerja sebagai berikut:

$$
\begin{aligned}
\mathrm{F}_{\mathrm{h}} & =\frac{\mathrm{R}^{2} / \mathrm{k}}{\left(1-\mathrm{R}^{2}\right) /(\mathrm{n}-\mathrm{k}-1)} \\
& =\frac{0,405^{2} / 2}{\left(1-0,405^{2}\right) /(100-2-1)} \\
& =9,509
\end{aligned}
$$

Berdasarkan hasil penghitungan di atas menggunakan rumus $\mathrm{F}$, diperoleh hasil untuk $\mathrm{F}_{\mathrm{h}}$ $=9,509$. Harga ini selanjutnya dikonsultasikan dengan $F$ tabel $\left(F_{t}\right)$, dengan dk pembilang $=k$ dan $\mathrm{dk}$ penyebut $=(\mathrm{n}-\mathrm{k}-1)$ dan taraf kesalahan yang ditetapkan adalah $5 \%$. F tabel yang diperoleh yaitu $F_{t}=3,09$. Dalam hal ini berlaku ketentuan bila $F_{h}$ lebih besar dari $F_{t}$, maka koefisien korelasi ganda yang diuji adalah signifikan, yaitu dapat diberlakukan untuk seluruh populasi. Dari perhitungan di atas, ternyata $F_{h}$ lebih besar dari $F_{t}(9,509>3,09)$ maka dapat dinyatakan bahwa korelasi ganda tersebut signifikan dan dapat diberlakukan terhadap keseluruhan populasi penelitian.

\section{Kesimpulan}

Berdasarkan hasil dari proses analisis data yang telah terkumpul pada penelitian tentang pengaruh kepemimpinan dan pendidikan terhadap kinerja prajurit dalam mendukung pertahanan di Lebanon Selatan nasional dengan studi di Satuan Tugas Force Protection Company XXVI-L2, maka dapat ditarik beberapa kesimpulan sebagai berikut:

1. Kepemimpinan secara signifikan berpengaruh positif terhadap kinerja prajurit Satuan Tugas Force Protection Company XXVI-L2 di Lebanon Selatan.

2. Pendidikan secara signifikan berpengaruh positif terhadap kinerja prajurit Satuan Tugas Force Protection Company XXVI-L2 di Lebanon Selatan.

3. Kepemimpinan dan pendidikan secara bersama-sama berpengaruh positif terhadap kinerja prajurit Satuan Tugas Force Protection Company XXVI-L2 di Lebanon Selatan secara signifikan. 


\section{Bibliografi}

Amstrong, M., \& Baron, A. (2004). Performance management. Yogyakarta: Tugu Publisher.

Bastian, I. (2001). akutansi sektor publik, Edisi pertama. Yogyakarta: Badan Penerbit Fakultas Ekonomi UGM.

Cobban, H. (1984). The Palestinian Liberation Organisation: people, power and politics. Cambridge University Press.

Diku, E. (2020). Peranan Pemimpin Agama Terhadap Perdamaian Internasional (Studi Kasus: Konflik Lebanon). Universitas Hasanuddin.

Perry, A. G., \& Potter, P. a. (2016). Buku Ajar Fundamental Keperawatan; Konsep, proses, dan praktik. Volume 1.

Prakoso, A. (2007). Perlindungan hukum terhadap anak dalam konflik bersenjata internasional antara Israel dan Libanon (studi normatif tentang implementasi konvensi Jenewa iv 1949).

Priatna, T. (2004). Reaktualisasi Paradigma Pendidikan Islam: Ikhtiar Mewujudkan Pendidikan Bernilai Ilahiah dan Insaniah di Indonesia (Vol. 1). Pustaka Bani Quraisy.

Sugiyono. (2018). Metode Penelitian Kuantitafif. Alfabeta.

Yuniarti, D., \& Suprianto, E. (2020). Pengaruh gaya kepemimpinan dan tingkat Pendidikan terhadap kinerja karyawan pada direktoreat operasi/produksi PT. X. Jurnal Industri Elektro Dan Penerbangan, 4(2).

Zahar, M.-J. (2005). Power sharing in Lebanon: Foreign protectors, domestic peace, and democratic failure. na. 